\title{
The effect of CdSe-ZnS quantum dots on calcium currents and catecholamine secretion in mouse chromaffin cells
}

\author{
Sara Gosso, Daniela Gavello, Carlo N.G. Giachello, Claudio Franchino, Emilio Carbone, Valentina Carabelli* \\ Department of Neuroscience, NIS Center, National Institute of Neuroscience, University of Torino, Corso Raffaello 30, 10125 Torino, Italy
}

\section{A R T I C L E I N F O}

\section{Article history:}

Received 4 July 2011

Accepted 10 August 2011

Available online 27 August 2011

\section{Keywords:}

Semiconductor nanocrystals

Adrenal chromaffin cells

Voltage-gated $\mathrm{Ca}^{2+}$ channels

Membrane capacitance changes

Exocytosis

Amperometry

\begin{abstract}
A B S T R A C T
Semiconductor nanocrystal quantum dots (QDs) possess an enormous potential of applications in nanomedicine, drug delivery and bioimaging which derives from their unique photoemission and photostability characteristics. In spite of this, however, their interactions with biological systems and impact on human health are still largely unknown. Here we used neurosecretory mouse chromaffin cells of the adrenal gland for testing the effects of $\mathrm{CdSe}-\mathrm{ZnS}$ core-shell quantum dots $(5-36 \mathrm{nM})$ on $\mathrm{Ca}^{2+}$ channels functionality and $\mathrm{Ca}^{2+}$-dependent neurosecretion. Prolonged exposure $(24 \mathrm{~h})$ to commonly used concentrations of CdSe-ZnS QDs $(\geq 16 \mathrm{nM})$ showed that the semiconductor nanocrystal is effectively internalized into the cells without affecting cell integrity (no changes of membrane resistance and cell capacitance). QDs reduced the size of $\mathrm{Ca}^{2+}$ currents by $\sim 28 \%$ in a voltage-independent manner without affecting channel gating. Correspondingly, depolarization-evoked exocytosis, measured at $+10 \mathrm{mV}$, where $\mathrm{Ca}^{2+}$ currents are maximal, was reduced by $29 \%$. CdSe-ZnS QDs reduced the size of the readily releasable pool (RRP) of secretory vesicles by $32 \%$, the frequency of release by $33 \%$ and the overall quantity of released catecholamines by $61 \%$, as measured by carbon fibers amperometry. In addition, the $\mathrm{Ca}^{2+}$-dependence of exocytosis was reduced, whereas the catecholamine content of single granules, as well as the kinetics of release, remained unaltered. These data suggest that exposure to CdSe-ZnS QDs impairs $\mathrm{Ca}^{2+}$ influx and severely interferes with the functionality of the exocytotic machinery, compromising the overall catecholamine supply from chromaffin cells.
\end{abstract}

(c) 2011 Elsevier Ltd. All rights reserved.

\section{Introduction}

Quantum dots (QDs) are fluorescent semiconductor nanocrystals, whose basic structure is composed of a core semiconductor, typically CdSe or CdTe, enclosed in a shell of another semiconductor, such as zinc sulfide $(\mathrm{ZnS})$. An additional coating can be added to the fluorescent nanocrystal and QDs functionalization may improve their solubility and preserve their non-aggregated state [1,2]. Shell coatings may also be useful for attaching conjugates to trace therapeutic and diagnostic macromolecules, receptor ligands, or antibodies [3].

QDs are among the most promising nanostructures for in vitro diagnostic applications such as cancer diagnosis and therapy [4,5]. Due to their robust and bright light emission, QDs are widely employed for in vitro and in vivo imaging and recent developments, related to their surface coating and bio-conjugation schemes, have made them most suitable as single particle tracking probes in living cell applications [6-8]. QDs have been used for distinguishing full

\footnotetext{
* Corresponding author. Tel.: +39 (0)11 670 8488; fax: +39 (0)11 6708174.

E-mail address: valentina.carabelli@unito.it (V. Carabelli).
}

collapse fusion from kiss and run events at small central nervous system (CNS) nerve terminals [9], or as indicators for movements of $\mathrm{Ca}^{2+}$ activated BK channels [10]. However, while the potential of these products holds great promise [11,12], QDs toxicity has been investigated in a variety of tissues and cell lines and it is not clear what may be their adverse effects on human health $[13,14]$. QDs toxicity varies among the tissues and depends on QDs core structure, coating and functionalization [15]. Most studies reveal that toxicity is mainly associated to the core metal constituents $\left(\mathrm{Cd}^{2+}\right.$ and $\mathrm{Zn}^{2+}$ ), which can be dispersed in the cytosol. Thus, while coating appears as a solution for limiting the release of free metals from the core, their release over prolonged periods has not yet been comprehensively understood [16].

Here we focused on the commercially available and mostly used carboxyl CdSe/ZnS QDs which are highly soluble in aqueous solutions and can be coupled to a variety of macromolecules. QDs functionalization with carboxyl, as well as with amino, hydroxyl and thiol groups, is rather critical. It varies the hydrodynamic radius of the nanoparticle and surface modifications may drastically alter the spectral properties, nanoparticle stability and the interaction with biological samples [14,17]. A detailed overview concerning the 
physical-chemical properties of QDs, their toxicity and biological fate has recently appeared $[13,18]$.

Focusing on CdSe/ZnS QDs, the cytotoxic effects depend clearly on the biological sample, the QDs functionalization and coating. Internalized carboxyl $\mathrm{CdSe} / \mathrm{ZnS}$ nanoparticles impair chondrogenesis in mesenchymal stem cells [19] and are retained in the cornea up to 26 days [20]. They also increase intracellular $\mathrm{Ca}^{2+}$ in macrophages [21] and rat hippocampal neurons, whereas unmodified CdSe QDs potentiate both $\mathrm{Ca}^{2+}$ influx and $\mathrm{Ca}^{2+}$ release from the endoplasmic reticulum, and impair voltage-gated $\mathrm{Na}^{+}$ channels [22,23]. BNGF peptide-conjugated QDs activate TrkA receptors and initiate neuronal differentiation in PC12 cells [24] while acute applications of steptavidin-conjugated QDs impair the synaptic transmission and plasticity in "in vivo" rat hippocampal neurons [25]. To our knowledge little is known about the cytotoxic effects of QDs on neuronal excitability, voltage-gated ion channels and neurotransmitter release. This is a key missing issue that would help assessing the potential risks of using QDs in bioimaging of neuronal and neuroendocrine tissues. For this reason we used the chromaffin cells of the adrenal gland as an experimental model of neuronal-like cell secreting neurotransmitters.

The aim of the present study was to investigate whether carboxyl CdSe-ZnS core-shell quantum dots impair mouse chromaffin cell (MCC) functioning, focusing on the effects on $\mathrm{Ca}^{2+}$ influx through voltage-gated $\mathrm{Ca}^{2+}$ channels and related exocytosis. To the purpose we used conventional whole-cell patch clamp techniques to measure voltage-gated $\mathrm{Ca}^{2+}$ currents and the associated secretory responses viewed through membrane capacitance increases, whereas single exocytic events were detected by amperometric recordings. CdSe-ZnS QDs internalization was confirmed by confocal laser-scanning microscopy and reduced MCCs survival after CdSe-ZnS QDs exposure, evaluated by means of the Trypan Blue exclusion assay. Our results mainly concern QDs toxicity on cell viability and $\mathrm{Ca}^{2+}$-dependent events controlling neurotransmitter release in adrenal chromaffin cells.

\section{Materials and methods}

\subsection{Isolation and culture of mouse adrenal medulla chromaffin cells}

Mouse chromaffin cells (MCCs) were obtained from young C57BL/6] male mice (Harlan, Milano, Italy), which were killed by cervical dislocation and cultured as previously discussed [26]. All experiments were conducted in accordance with the guidelines on Animal Care established by the Italian Minister of Health and were approved by the local Animal Care Committee of Turin University After removal, the adrenal glands were placed in $\mathrm{Ca}^{2+}$ and $\mathrm{Mg}^{2+}$ free Locke's buffer, which contained

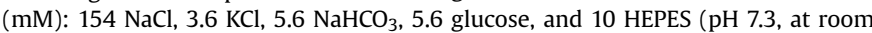
temperature). The glands were decapsulated, and the medullas were precisely separated from the cortical tissue. Medulla digestion was achieved after $20 \mathrm{~min}$ at $37^{\circ} \mathrm{C}$ in the enzyme digestion solution, containing DMEM enriched with: $0.16 \mathrm{mM} \mathrm{L}$ cysteine, $1 \mathrm{mM} \mathrm{CaCl}$, $0.5 \mathrm{mM}$ EDTA, $20 \mathrm{U} / \mathrm{ml}$ of papain (Worthington Biochemical, Lakewood, NJ, USA) plus $0.1 \mathrm{mg} / \mathrm{ml}$ of DNAse (Sigma, Milan, Italy). The digested glands were then washed twice, with a solution containing DMEM, $1 \mathrm{mM} \mathrm{CaCl}_{2}$, $10 \mathrm{mg} / \mathrm{ml} \mathrm{BSA}$, resuspended in $2 \mathrm{ml}$ DMEM supplemented with 15\% fetal bovine serum (FBS) (Invitrogen, Grand Island, NY, USA) and pipetted up and down gently to mechanical disaggregating of the glands.

Cells were plated in four-well plastic dishes pretreated with poly-L-ornithine $(0.5 \mathrm{mg} / \mathrm{ml})$ and laminin ( $10 \mathrm{mg} / \mathrm{ml}$ in L-15 carbonate). After $1 \mathrm{~h}, 1.8 \mathrm{ml}$ of DMEM supplemented with $15 \% \mathrm{FBS}, 50 \mathrm{IU} / \mathrm{ml}$ penicillin, and 10,000 $\mathrm{IU} / \mathrm{ml}$ streptomycin (Lonza Group Ltd., Basel, Switzerland), $10 \mu \mathrm{M}$ Cytosine b-D-arabino-furanosidehydrochloride (Sigma), $10 \mu \mathrm{M}$ 5-Fluoro-2'-deoxyuridine (Sigma) was added to the culture medium. Dishes were then incubated at $37{ }^{\circ} \mathrm{C}$ in a water-saturated atmosphere with $5 \% \mathrm{CO}_{2}$, and used within 2-4 days after plating.

\subsection{Electrophysiological recordings}

Voltage-clamp recordings were performed in the whole-cell perforated configuration by using an EPC-10 amplifier and Patch Master software (HEKA Elektronik, Lambrecht, Germany). Patch pipettes were made in borosilicate glass (Kimax 51; Witz Scientific, OH, USA) and filled with an internal solution containing (mM): $135 \mathrm{CsMeSO}_{3}, 8 \mathrm{NaCl}, 2 \mathrm{MgCl}_{2}, 20$ HEPES plus amphotericin $\mathrm{B}$, used at a final concentration of $500 \mu \mathrm{g} / \mathrm{ml}$; pH 7.3, using $\mathrm{CsOH}$. Pipettes' series resistance was 1-2 M $\Omega$. The external bath used as "control solution" contained (mM): 4 TEACl, 126 $\mathrm{NaCl}, 10 \mathrm{CaCl}_{2}, 4 \mathrm{KCl}, 2 \mathrm{MgCl}_{2}, 10$ Glucose, 10 HEPES, pH 7.4, with $\mathrm{NaOH}$. All the experiments were performed at room temperature. $\mathrm{Ca}^{2+}$ currents were sampled at $10 \mathrm{kHz}$ and filtered at $2 \mathrm{kHz}$

Depolarization-evoked exocytosis was measured as membrane capacitance increases $\left(\Delta C_{\mathrm{m}}\right)$ after depolarizing pulses. As described elsewhere [26], a sinusoidal wave function was superimposed on the holding potential $( \pm 25 \mathrm{mV}, 1 \mathrm{kHz})$, using the Lockin extension of the Patch Master software. The amount of $\mathrm{Ca}^{2+}$ entering in the cells during a depolarization (quantity of charge) was calculated as the time integral of the $\mathrm{Ca}^{2+}$ current and normalized to cell capacitance ( $\left.\mathrm{pC} / \mathrm{pF}\right)$. The RRP size was estimated using the double-pulse protocol [27].

For the membrane resistance measurements in current-clamp recordings the patch pipette was filled with an internal solution containing (mM): $135 \mathrm{KAsp}, 8 \mathrm{NaCl}$, $20 \mathrm{HEPES}, 2 \mathrm{MgCl}_{2}$, 5 EGTA plus amphotericin B, (final concentration of $500 \mu \mathrm{g} / \mathrm{ml}$ ), pH 7.3 using CsOH. The external solution contained (mM): $130 \mathrm{NaCl}, 2 \mathrm{CaCl}_{2}, 4 \mathrm{KCl}, 2$ $\mathrm{MgCl}_{2}, 10$ Glucose, 10 HEPES, pH 7.4 with $\mathrm{NaOH}$. The membrane resistance was evaluated by injecting $-10 \mathrm{pA}$ current pulse for $1 \mathrm{~s}$, and then measuring the membrane potential difference at the end of the pulse.

\subsection{Amperometric recordings}

We performed the amperometric recordings by using carbon fibers purchased from ALA Scientific Instrument Inc. (Westbury, NY, USA) and a HEKA EPC-10 amplifier. Carbon fibers ( $5 \mu \mathrm{m}$ diameter) were cut at an angle of $45^{\circ}$, polarized to $+800 \mathrm{mV}$ and positioned next to the cell membrane. MCCs were maintained into an extracellular solution containing (mM): $128 \mathrm{NaCl}, 2 \mathrm{MgCl}_{2}, 10$ glucose, 10 HEPES, $10 \mathrm{CaCl}_{2}, 4 \mathrm{KCl}$ and then stimulated using a $\mathrm{KCl}$-enriched solution, containing $(\mathrm{mM})$ : $100 \mathrm{NaCl}, 2 \mathrm{MgCl}_{2}, 10$ glucose, 10 HEPES, $10 \mathrm{CaCl}_{2}, 30 \mathrm{KCl}$.

Amperometric currents were sampled at $4 \mathrm{kHz}$, low-pass filtered at $1 \mathrm{kHz}$, monitored over 120 s. Finally, we analyzed the recordings by using IGOR macros (Wave-Metrics, Lake Oswego, OR, USA) as previously described [28].

\subsection{Cell staining and cytotoxicity assays}

Carboxyl QDs with CdSe core and ZnS shell, have been purchased from Invitrogen (Qdot ${ }^{\circledR} 585$ ITK $\left.^{\mathrm{TM}}, \mathrm{Q} 21311 \mathrm{MP}\right)$. These QDs have mean size of 7-8 nm, further coated with $-\mathrm{COO}^{-}$surface groups to achieve a polymer layer that allows facile dispersion of the QDs in aqueous solution with retention of the optical properties. TEM images of the core-shell are given in the Invitrogen data sheet as well as the absorption and emission spectra of CdSe-ZnS QDs nanocrystals. These latter are narrow and symmetrical with emission maxima near $585 \mathrm{~nm}$. Hydrodynamic diameter of $\mathrm{CdSe}-\mathrm{ZnS}$ QDs was estimated around $9.3 \mathrm{~nm}$ by means of dynamic light scattering (DLS) analysis [29]. The same authors characterized as well the synthesized CdSe/ZnS QD nanoparticles, furnishing TEM images and absorption/emission spectra.

Stock solution of the QDs ( $8 \mu \mathrm{M}$ in $50 \mathrm{mM}$ borate, $\mathrm{pH}$ 9), was diluted in culture medium to reach a final concentration of $5,8,16$ or $36 \mathrm{nM}$. One day after plating, MCCs were incubated for $24 \mathrm{~h}$ with CdSe-ZnS QDs; then culture medium was replaced and cells were ready for experiments.

Given our main interest on the effects of ODs on chromaffin cell functionality, cell viability after QDs exposure was tested using the Trypan Blue exclusion assay, which is a simple and rapid technique that stains dead/dying cells with compromised membrane integrity. Although less precise than the MTT assay [30], the Trypan Blue exclusion assay gives good estimates of drug toxicity on living cells [31]. Cells were counted by comparing the number of living (unstained) cells before and after $24 \mathrm{~h}$ QDs incubation. Cell counting was performed over 4 dishes of the same cultures for both QD-treated and control cells. Each dish was divided in 49 square areas of $500 \times 500 \mu \mathrm{m}^{2}$ and counting of the cells was in a total of 196 areas. Trypan Blue incubation (Sigma; 0.4\% final dilution) was performed $10 \mathrm{~min}$ before cell counting.

\subsection{Confocal microscopy}

Mouse chromaffin cells were exposed for $24 \mathrm{~h}$ to $16 \mathrm{nM}$ CdSe-ZnS QDs and then washed twice with media to remove any cell-associated dye. In each experiment, a parallel culture incubated with vehicle solution was used as control.

Conventional immunofluorescence procedures were performed to counterstain samples for actin filaments. Briefly, after fixation with $4 \%$ paraformaldehyde in phosphate-buffered saline (PBS), cells were permeabilized $\left(\mathrm{PBS}^{+}, \mathrm{PBS}\right.$ containing $0.2 \%$ Triton $\mathrm{X}-100)$ and blocked $\left(1.5 \%\right.$ normal donkey serum in $\left.\mathrm{PBS}^{+}\right)$. Actin cytoskeleton was visualized by staining for $2 \mathrm{~h}$ with a monoclonal anti- $\beta$ actin mouse antibody (A5441, Sigma) diluted 1:500 in $\mathrm{PBS}^{+}$, followed by an Alexa Fluor 488labeled donkey anti-mouse IgG (1:500 in $\mathrm{PBS}^{+}$for $1 \mathrm{~h}$; A21202, InVitrogen, Molecular Probes, Oregon, USA).

Fluorescence signals were detected with a Fluoview 300 confocal laser-scanning microscope (Olympus, Hamburg, Germany). Image acquisition has been performed over 4 control and 4 treated dishes. Stacks of images from consecutive $1 \mu \mathrm{m}$-thick slices were processed with Adobe Photoshop (Adobe Systems, Mountain View, CA). 
The same microscope settings (laser power, filters, detector gain, amplification gain) were used for both treated and control samples. Stacks of images from consecutive $1 \mu \mathrm{m}$-thick slices were processed with Adobe Photoshop (Adobe Systems, Mountain View, CA).

\section{Results}

\subsection{CdSe-ZnS QDs internalization in MCCs}

QD nanoparticles internalization may occur through different pathways [3], involving either clathrin-mediated endocytosis, macropinocytosis [32-34], or directed to the receptor system, in the case of ligand-conjugated QDs [35,36]. Concerning CdSe-ZnS QDs, internalization occurs passively in human mammary cells along three major pathways: endocytosis, sequestration in early endosomes, translocation to later endosomes or lysosomes [37]. Here we used confocal imaging to monitor CdSe-ZnS QDs (16 nM) internalization in living chromaffin cells after $24 \mathrm{~h}$ incubation. As illustrated in Fig. 1-left, consecutive confocal $2 \mu \mathrm{m}$ z-stack images showed the presence of granule-like red fluorescence spots inside the QDs-treated cells. As observed in other cell preparations [38-40], there was no detectable QD fluorescence in the nucleus. In parallel, no signal was detected in control cells incubated with vehicle (control) solution (right panels). Co-immunolabeling with an antibody specific for $\beta$-actin (green image) confirmed the internalization of QDs and helped delineating cell borders and shape.

\subsection{MCCs viability after QDs exposure}

Although studying cytotoxicity and genotoxicity of CdSe-ZnS was beyond the purpose of the present study, we thought nevertheless important to check the effect of $24 \mathrm{~h}$ exposure to $16 \mathrm{nM}$ QDs on MCC survival [41]. Chromaffin cell viability was monitored by the Trypan Blue exclusion assay (see Materials and methods). This organic dye selectively stains dead/dying cells. $24 \mathrm{~h}$ after incubation, the density of unstained living cells were approximately $14.6 \pm 0.8$ cells $/ \mathrm{mm}^{2}$ under control conditions (Fig. 2A) and decreased to $6.6 \pm 0.5$ cells $/ \mathrm{mm}^{2}$ with CdSe-ZnS QDs $(p<0.001)$. Since CdSe-ZnS QDs were suspended in the culture medium, we cannot exclude that some aggregation of nanoparticles may have occurred, down scoring cell toxicity [42]. Interestingly, also in hippocampal neurons treated with CdSe QDs, viability was
A
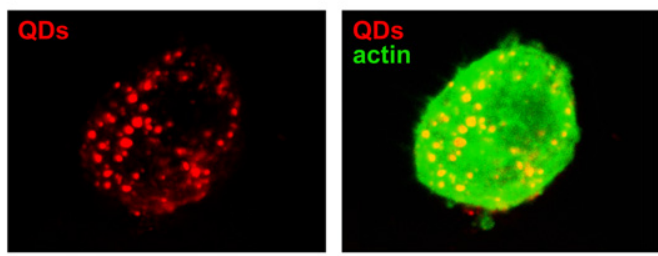

16 nM QDs incubation

B
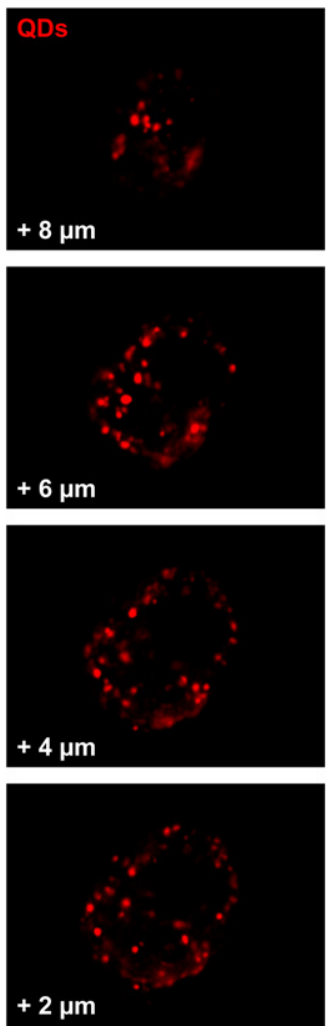
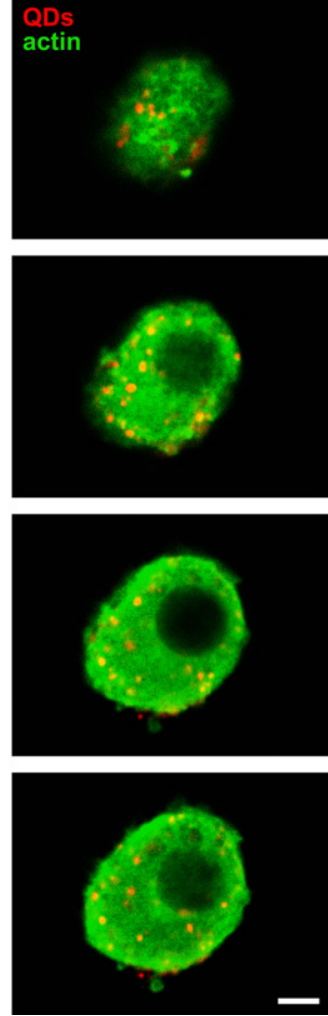
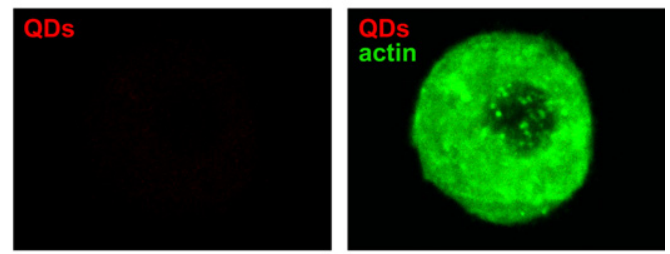

control
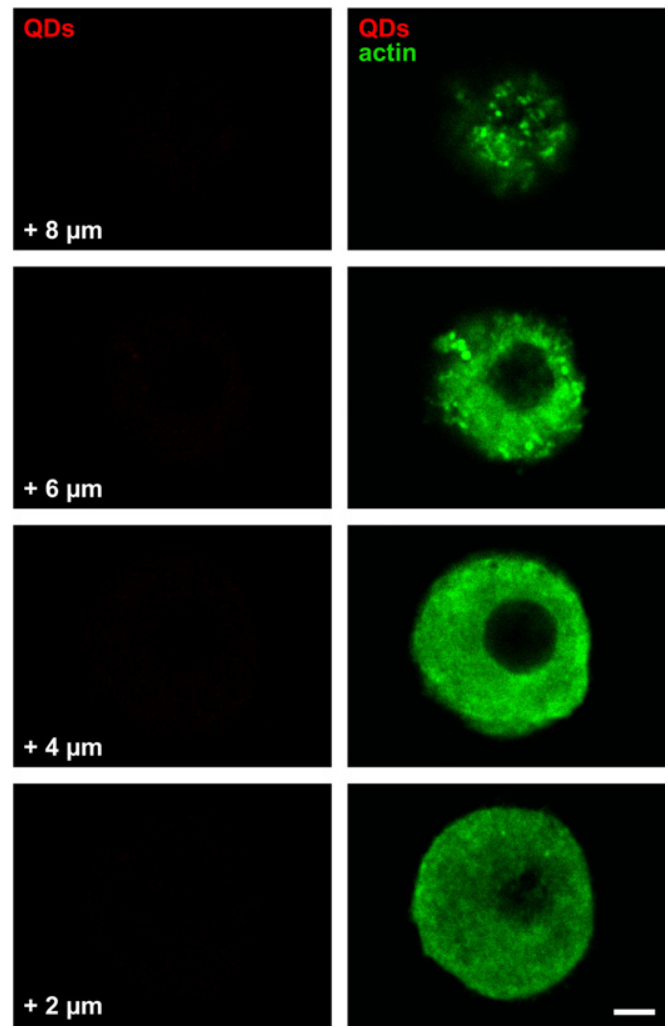

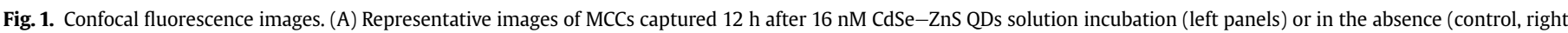

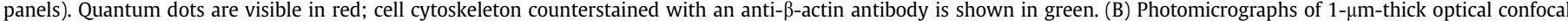

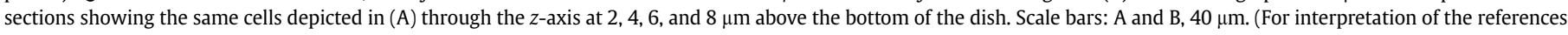
to colour in this figure legend, the reader is referred to the web version of this article.) 

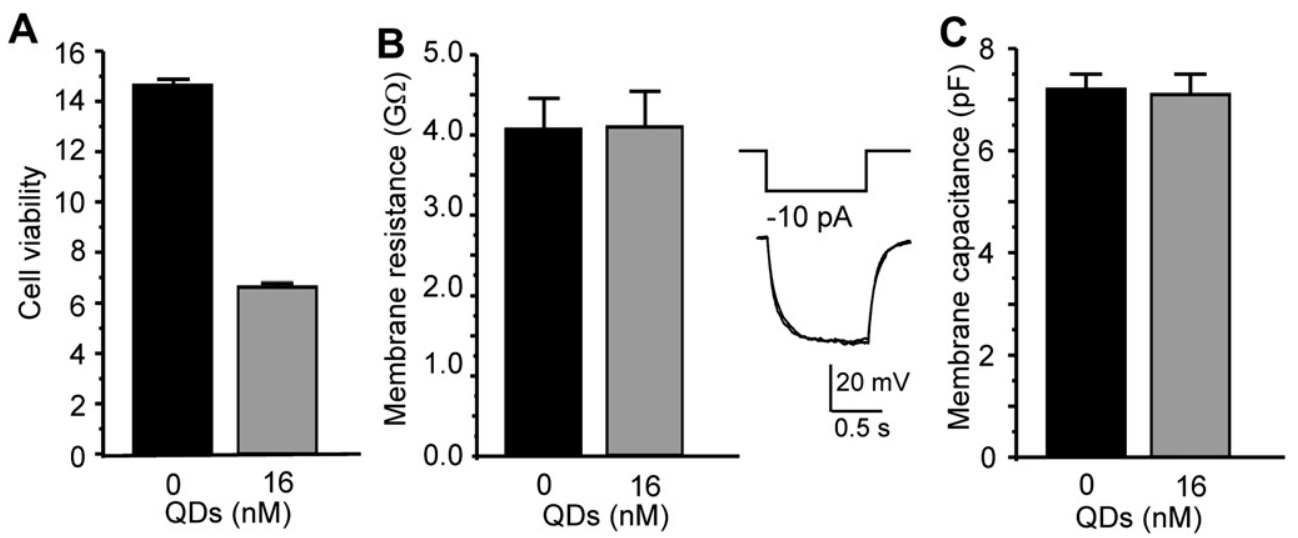

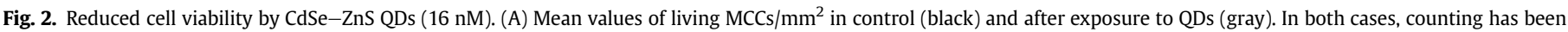

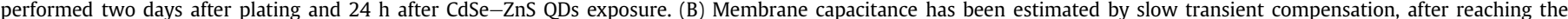

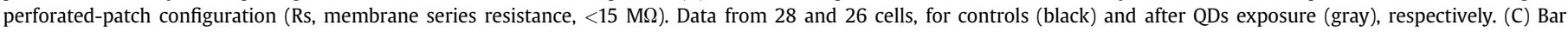

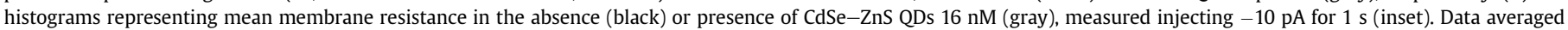
from 18 and 19 cells, for controls and after QDs exposure, respectively.

significantly reduced at concentrations higher than $10 \mathrm{nM} \mathrm{[23]} \mathrm{and}$ similar results were found for CdSe-ZnS QDs, which affected corneal fibroblast viability by approximately $28 \%$ after $24 \mathrm{~h}$ incubation [20].

\subsection{Effects of CdSe-ZnS QDs on cell capacitance and input resistance}

In order to investigate whether CdSe-ZnS QDs exposure (16 nM, $24 \mathrm{~h}$ ) could alter cell membrane integrity, we measured the cell input resistance $\left(R_{\mathrm{m}}\right)$ by injecting $-10 \mathrm{pA}$ current pulse $(1 \mathrm{~s})$ from $-80 \mathrm{mV}$ holding potential $\left(V_{\mathrm{h}}\right)$ and monitoring the corresponding $\Delta V$ change. On average, controls and QDs-treated cells had the same $R_{\mathrm{m}}, 4.1 \pm 0.4 \mathrm{G} \Omega$ in control and after QDs exposure (Fig. 2B), in good agreement with previously reported values [43]. Membrane capacitance $\left(C_{\mathrm{m}}\right)$, estimated through the slow transient cancellation $\left(C_{\text {slow }}\right)$, was $8.0 \pm 0.4 \mathrm{pF}$ in control conditions and $7.2 \pm 0.3 \mathrm{pF}$ after CdSe-ZnS QDs exposure $(p=0.14)$, suggesting that QDs do not affect the membrane surface area and resting resistance (leakage currents) of MCCs (Fig. 2C).

\subsection{Saturation of $\mathrm{Ca}^{2+}$ currents reduction at high $\mathrm{CdSe}-\mathrm{ZnS} \mathrm{QDS}$ concentrations}

Chromaffin cells of the adrenal gland express L, N, P/Q and Rtype $\mathrm{Ca}^{2+}$ channels, which contribute to secretory responses according to their density of expression [44]. Thus, our aim was to understand whether CdSe-ZnS QDs exposure could affect $\mathrm{Ca}^{2+}$ channels functionality and $\mathrm{Ca}^{2+}$-dependent exocytosis. For this purpose, we first tested the effects of increasing concentrations of CdSe-ZnS QDs (5 nM-36 nM).

$\mathrm{Ca}^{2+}$ currents were measured from -40 to $+40 \mathrm{mV}$, holding the cells to $V_{\mathrm{h}}=-80 \mathrm{mV}$. As shown in Fig. 3, exposure to 5 and $8 \mathrm{nM}$ $\mathrm{CdSe}-\mathrm{ZnS}$ QDs caused little changes to $\mathrm{Ca}^{2+}$ current amplitudes with respect to control cells $(p>0.05) . \mathrm{Ca}^{2+}$ currents were significantly reduced when applying $16 \mathrm{nM}$ and showed no further reduction at $36 \mathrm{nM} \mathrm{CdSe-ZnS}$ QDs. Mean $\mathrm{Ca}^{2+}$ current amplitudes measured at $+10 \mathrm{mV}$ showed maximal depression of $26 \pm 6 \%$ (Fig. 3A), suggesting saturating conditions between 16 and $36 \mathrm{nM}$ with an $\mathrm{IC}_{50}$ of about $9 \mathrm{nM}$ (Fig. 3B), in good agreement with previously reported $\mathrm{IC}_{50}$ of QD cytotoxic effects [39]. Comparable $\mathrm{IC}_{50}$ values were obtained at 0 and $+20 \mathrm{mV}$. Representative $\mathrm{Ca}^{2+}$ current traces at 5 and $36 \mathrm{nM}$ CdSe-ZnS QDs are shown in Fig. 3A, inset.

\subsection{Voltage-independent inhibition of $\mathrm{Ca}^{2+}$ currents by $\mathrm{CdSe}-\mathrm{ZnS}$ QDs}

Once set the saturating concentrations of QDs we next studied the voltage-dependence of QDs effects by applying ramp commands from $-80 \mathrm{mV}$ to $+60 \mathrm{mV}$ for $150 \mathrm{~ms}$. We found that $\mathrm{CdSe}-\mathrm{ZnS}$ QDs reduced the maximum current amplitude from $-49 \pm 4 \mathrm{pA} / \mathrm{pF}(n=28)$ to $-35 \pm 3 \mathrm{pA} / \mathrm{pF}(n=26, p<0.01)$, with no effects on the voltage of maximal $\mathrm{Ca}^{2+}$ currents: $14.3 \pm 1.5 \mathrm{mV}$ and $13.5 \pm 1.7 \mathrm{mV}$ for controls and QDs-treated cells, respectively (Fig. 4A). Reduction of $\mathrm{Ca}^{2+}$ currents was further investigated by applying step commands, consisting of voltage steps of increasing amplitude from -40 to $+50 \mathrm{mV}$ lasting $50 \mathrm{~ms}$ (Fig. 4B). Peak $\mathrm{Ca}^{2+}$ currents $\left(I_{\mathrm{p}}\right)$ were similarly inhibited in the whole range of potentials examined ( $28 \pm 4 \%)$, suggesting that the depressive action exerted by QDs was mostly voltage-independent and caused no changes to the $\mathrm{Ca}^{2+}$ reversal potential $(\sim+58 \mathrm{mV})$. Reduction of $\mathrm{Ca}^{2+}$ currents by CdSe-ZnS QDs was the same if either measured at the peak of the current or at the steady-state $\left(I_{\mathrm{sS}}\right)$ $(27 \pm 6 \%)$, indicating that QDs have little or no effects on fast $\mathrm{Ca}^{2+}$ channel inactivation (Fig. 4D). Interestingly, a similar depression was observed on the tail current amplitude $\left(I_{t}\right)$ measured on return to $-80 \mathrm{mV}$. Comparing $I_{\mathrm{ss}}$ at $+20 \mathrm{mV}$ and $I_{\mathrm{t}}$ at $-80 \mathrm{mV}$ on the same cell, we found that the mean ratio $I_{s s} / I_{\mathrm{t}}$ was nearly unchanged in control and QDs-treated cells ( $0.45 \pm 0.03$ vs. $0.43 \pm 0.03$ for $n=14$ to 19 cells; $p>0.5$ ), suggesting that $\mathrm{Ca}^{2+}$ current depression is insensitive to voltage also at very negative potentials. This would exclude a possible block of $\mathrm{Ca}^{2+}$ channels by free intracellular $\mathrm{Cd}^{2+}$ or $\mathrm{Zn}^{2+}$ ions released from the inner and outer shell of QDs. A hypothetical block of the $\mathrm{Ca}^{2+}$ channel pore by internal $\mathrm{Cd}^{2+}$ or $\mathrm{Zn}^{2+}$ would be largely removed at very negative potentials by the inward passage of $\mathrm{Ca}^{2+}$ ions and/or lowering of the energy barrier controlling the exit rate of $\mathrm{Cd}^{2+}$ or $\mathrm{Zn}^{2+}$ from their binding site inside the pore (see Discussion). Tail currents at $-80 \mathrm{mV}$ in the presence of QDs would be only little attenuated and the ratio $I_{\mathrm{sS}} / I_{\mathrm{t}}$ would be significantly $<0.45$ in the case of a "voltage-dependent" block by $\mathrm{Cd}^{2+}$ or $\mathrm{Zn}^{2+}$.

QDs had also no effects on the voltage-dependence of channel activation, as suggested by the almost unaltered rise time of activation $\left(t_{10-90}\right)$ measured between $-30 \mathrm{mV}$ and $+20 \mathrm{mV}$ in control 
A

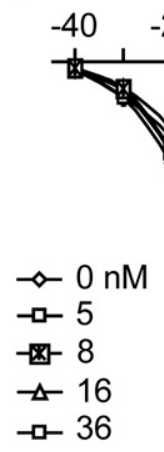

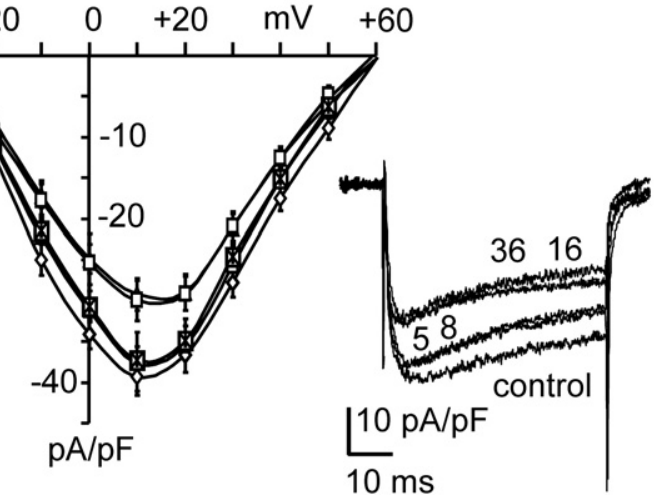

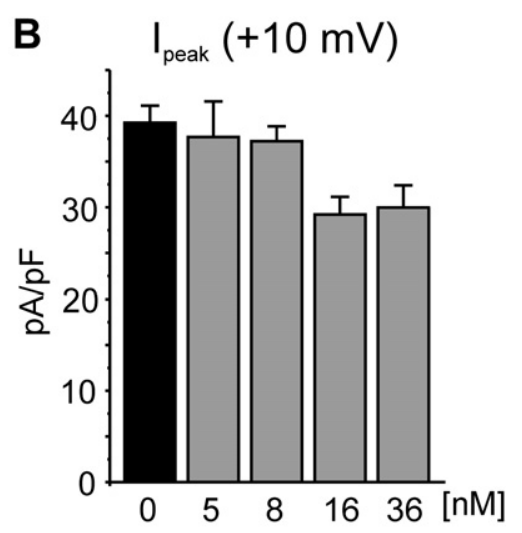

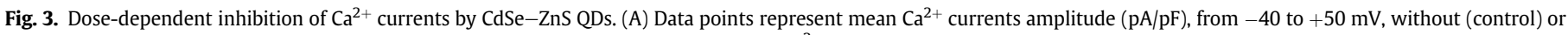

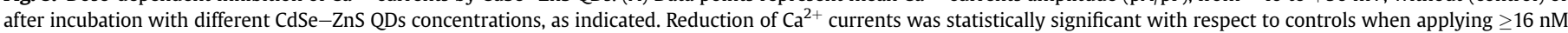

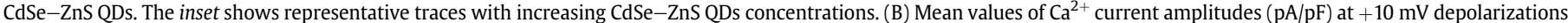
with increasing CdSe-ZnS QDs concentrations. IC $_{50}$ was $9.1 \pm 0.7 \mathrm{nM}$.

and QDs-treated cells $(2.09 \pm 0.12 \mathrm{~ms}$ vs $2.4 \pm 0.2 \mathrm{~ms}$ at $+10 \mathrm{mV}$, Fig. 4C). Taken together these findings suggest that QDs do not alter $\mathrm{Ca}^{2+}$ channel gating, but rather reduce the overall $\mathrm{Ca}^{2+}$ channel conductance by either reducing $\mathrm{Ca}^{2+}$ channel availability (\% of functioning channels), probability of channel opening or single channel conductance. Although a reduced $\mathrm{Ca}^{2+}$ channel availability appears the most reasonable cause, a final statement should wait for measurements of unitary $\mathrm{Ca}^{2+}$ currents in membrane micro areas [45]. In addition, a selective inhibitory effect on either one of the $\mathrm{Ca}^{2+}$ channel isoforms expressed by MCCs (L, N, P/Q R) $[43,46]$ cannot be excluded from the present data.

\subsection{Decreased depolarization-evoked secretion after $\mathrm{CdSe}-\mathrm{ZnS}$ QDs exposure}

In order to test how QDs alter catecholamine secretion we measured the depolarization-evoked capacitance increases $\left(\Delta C_{\mathrm{m}}\right)$, the size of the readily releasable pool (RRP) and the $\mathrm{Ca}^{2+}$-dependence of exocytosis. In control conditions, cell depolarizations of $100 \mathrm{~ms}$ to $+10 \mathrm{mV}$ produced a mean quantity of charge equal to $2.8 \pm 0.2 \mathrm{pC} / \mathrm{pF}$ and a corresponding mean $\Delta C_{\mathrm{m}}$ of $41 \pm 5 \mathrm{fF}(n=14)$. After $24 \mathrm{~h}$ incubation with CdSe-ZnS QDs (16 nM), the amount of mean charges decreased to $2.1 \pm 0.3 \mathrm{pC} / \mathrm{pF}(p<0.05)$, and correspondingly $\Delta C_{\mathrm{m}}$ was reduced to $29 \pm 3 \mathrm{fF}(n=17)$, showing a significant decrease with respect to control MCCs $(p<0.01$, Fig. 5A and B). Thus, CdSe-ZnS QDs exposure significantly reduced both the quantity of $\mathrm{Ca}^{2+}$ entry and the related depolarization-evoked capacitance increases in MCCs. Furthermore, by measuring the size of the readily releasable pool (RRP), we estimated a mean RRP of $117 \pm 16 \mathrm{fF}$ in the absence of QDs (18 cells) that decreased to $80 \pm 6 \mathrm{fF}$ in QDs-treated cells $(n=17)(p<0.05$, Fig. 5C and D). Fig. 5D shows also that $16 \mathrm{nM}$ QDs incubation causes a net decrease of the probability of vesicle fusion and secretion defined as $p=1-\Delta C_{2} / \Delta C_{1}$ [27]: $0.57 \pm 0.04$ and $0.48 \pm 0.02(p<0.05)$ in control and after CdSe-ZnS QDs treatment. In conclusion, our data suggest that CdSe-ZnS QDs impair secretion from MCCs mainly by reducing $\mathrm{Ca}^{2+}$ entry through voltage-gated $\mathrm{Ca}^{2+}$ channels, decreasing the size of RRP and lowering the probability of release. By plotting $\Delta C$ values versus the density of $\mathrm{Ca}^{2+}$ charges entering the cell during step depolarizations $(+10 \mathrm{mV})$ of fixed length $(100 \mathrm{~s})$ we could also estimate the $\mathrm{Ca}^{2+}$-dependence of secretory responses (Fig. 5E). We found that $\mathrm{CdSe}-\mathrm{ZnS}$ QDs (16 $\mathrm{nM}$ ) reduced the slope of the linear $\mathrm{Ca}^{2+}$-dependence of secretion: $13.2 \pm 1.4 \mathrm{fF} /$ ( $\mathrm{pC} / \mathrm{pF}$ ) (controls) versus $10.5 \pm 1.2 \mathrm{fF} /(\mathrm{pC} / \mathrm{pF}$ ) for $\mathrm{QDs}$, respectively.
As for $\mathrm{Ca}^{2+}$ currents, secretory responses were studied at increasing doses of QDs, starting from 5 to $36 \mathrm{nM}$. Fig. 6 shows the decrease of quantity of charge ( $\mathrm{Ca}^{2+}$ ions), and related $\Delta C_{\mathrm{m}}$, versus increasing CdSe-ZnS QDs concentrations. Data were averaged over a variable number of cells (see figure legend) obtaining $\mathrm{IC}_{50}$ equal to $9 \pm 5 \mathrm{nM}$. Depolarization-evoked capacitance changes decreased from $41 \pm 5 \mathrm{fF}$ (controls) to $28 \pm 4 \mathrm{fF}$, when the maximal concentration was applied $(36 \mathrm{nM})$; in this case $\mathrm{IC}_{50}$ was $6 \pm 2 \mathrm{nM}$. Increasing concentrations of QDs reduced the size of the RRP, as well. Already at CdSe-ZnS QDs $5 \mathrm{nM}$, we estimated a significant decrease from $117 \pm 16 \mathrm{fF}$ to $74 \pm 12 \mathrm{fF}(p<0.05)$.

\subsection{Effects of $C d S e-Z n S Q D s$ on the frequency and shape of quantal secretory events}

Single exocytotic events in MCCs were investigated using carbon fiber electrodes polarized to $+800 \mathrm{mV}$ [26]. Exocytosis was stimulated by a $\mathrm{KCl}$-enriched external solution ( $30 \mathrm{mM}$, see Methods). Amperometric currents, from control and CdSe-ZnS QDs-treated cells, were monitored over 2 min (Fig. 7A) and analyzed as previously described [28]. Frequency of amperometric spikes was the only parameter significantly modified by QDs (Fig. 7B). Mean frequency was $0.52 \pm 0.07 \mathrm{~Hz}$ ( $n=20$ control cells, 1253 spikes) and decreased to $0.35 \pm 0.04 \mathrm{~Hz}(n=22$ QDs-treated cells, 919 spikes, $p<0.05$ ), thus confirming that QDs reduce the probability of vesicle fusion and catecholamine release, as determined by the doublepulse protocol used for estimating the RRP (Fig. 5D). The decreased frequency of secretory events gave rise to a drastic reduction of the cumulative secreted charges (oxidized adrenaline and noradrenaline) over 2 min recordings. Fig. 7B shows the mean cumulative secreted charges averaged over $n=20$ control and $n=22$ QDs-treated cells. At the end of the stimulation, maximal cumulative charge decreased by $61 \pm 12 \%$, from $17 \pm 4 \mathrm{pC}$ (control) to $6.6 \pm 1.3 \mathrm{pC}(\mathrm{QDs})$, thus confirming that the reduced frequency of released secretory granules drastically affects exocytosis in MCCs.

On the contrary, the analysis of the amperometric spike parameters revealed that QDs did not significantly alter either the maximal oxidation current ( $I_{\max }$, from $39 \pm 5 \mathrm{pA}$ to $32 \pm 6 \mathrm{pA}$ ), the cube root of the charge $\left(Q^{1 / 3}\right.$, from $0.54 \pm 0.02 \mathrm{pC}^{1 / 3}$ to $0.50 \pm 0.02 \mathrm{pC}^{1 / 3}$ ) or the spike's kinetic parameters (Table 1 ). By analyzing the distribution of $Q^{1 / 3}$ values, control data were fitted with a double Gaussian function with peaks at $0.47 \pm 0.01 \mathrm{pC}^{1 / 3}$ (59\%) and $0.69 \pm 0.1 \mathrm{pC}^{1 / 3}(41 \%)$, in good agreement with previously reported data $[26,47]$. In the presence of QDs, the two peaks of the 

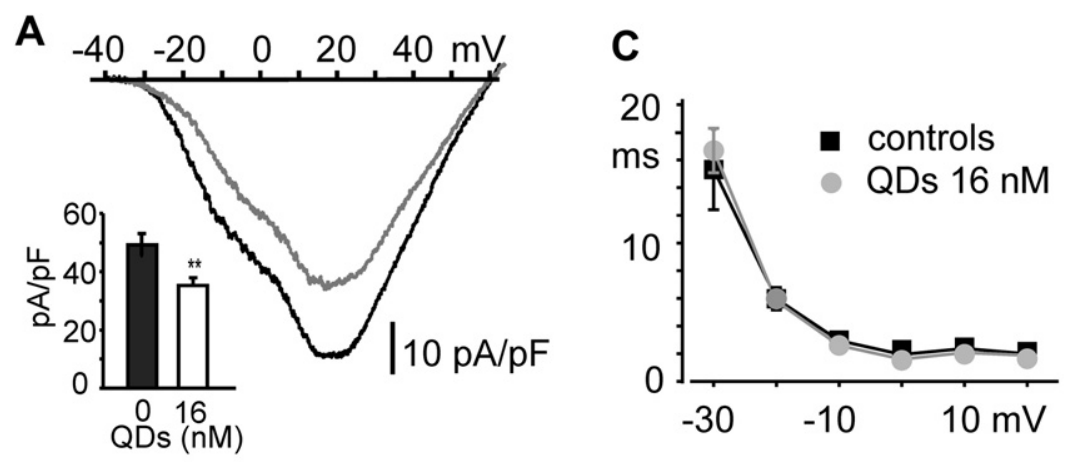

B

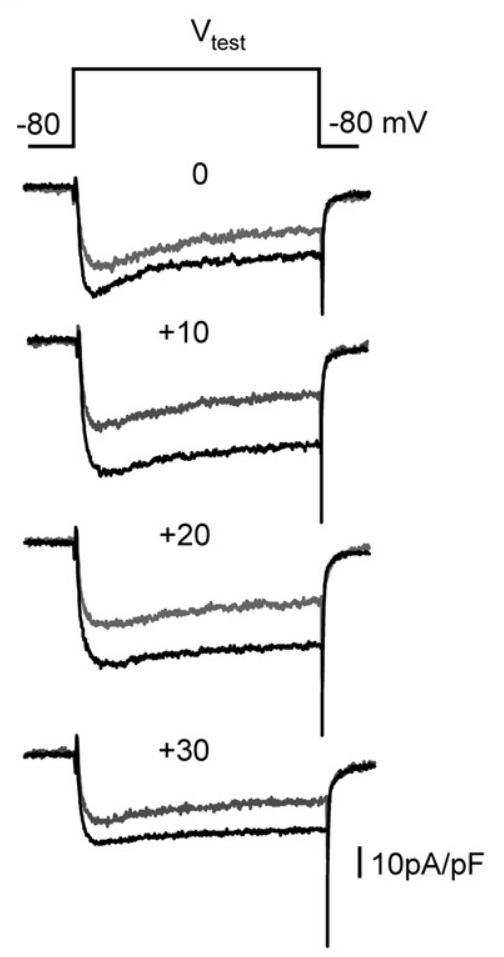

D

$\mathrm{I}_{\mathrm{p}}$ peak amplitude

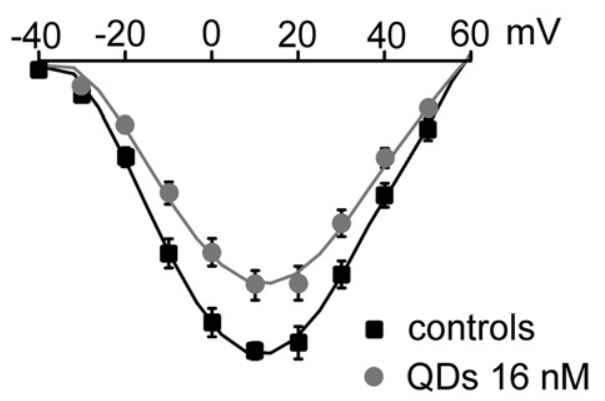

$\mathrm{I}_{\mathrm{ss}}$ steady state amplitude

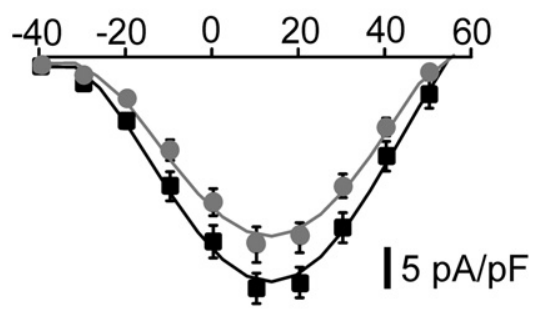

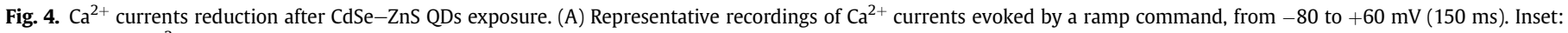

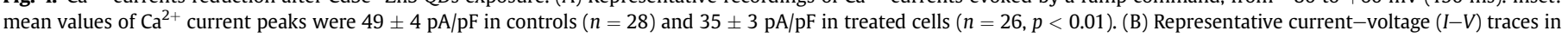

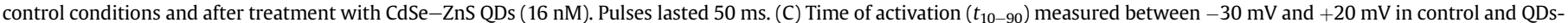

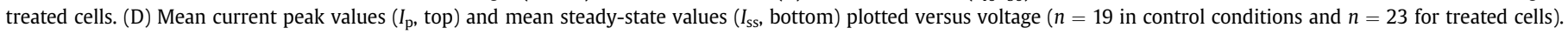

bimodal distribution were not significantly changed, centered around $0.40 \pm 0.04 \mathrm{pC}^{1 / 3}$ and $0.7 \pm 0.2 \mathrm{pC}^{1 / 3}$, and respectively contributing by $80 \%$ and $20 \%$ to the total area (Fig. $7 \mathrm{C}$ ); furthermore, it is worth noticing that the percentage of vesicles with higher charge was drastically reduced in presence of QDs. As a final remark, it should be noted that despite all the parameters of Table 1 $\left(I_{\max }, Q, t_{1 / 2}\right)$ are statistically unchanged, they are systematically smaller by $10 \%-20 \%$ with respect to control. Thus, it is likely that taken altogether and summed to the 33\% decreased frequency of amperometric bursts they account for the $61 \%$ depression of the total quantity of catecholamine released, which is the most depressive effect of QDs on MCCs functioning.

\section{Discussion}

Using chromaffin cells as an experimental model for monitoring $\mathrm{Ca}^{2+}$-dependent secretory processes $[26,28,44,48]$, we provided evidence that $\mathrm{CdSe}-\mathrm{ZnS}$ quantum dots reduce $\mathrm{Ca}^{2+}$ fluxes and $\mathrm{Ca}^{2+}$-dependent catecholamine secretion. Given the wide usage of QDs to trace biomolecules and molecular processes in living tissues, these findings are of relevance for understanding QDs cytotoxicity on adrenal chromaffin cell functioning. Further experiments should clarify whether our conclusions can be extrapolated to other hormone-releasing cells, belonging to zona fasciculata, glomerulosa and reticularis of the same gland or to other neuroendocrine tissues, such as pancreatic and pituitary cells, and thus help understanding how QDs could interfere with the molecular mechanisms regulating $\mathrm{Ca}^{2+}$-dependent vesicle release in central synapses.

Concerning the action of QDs on voltage-gated $\mathrm{Ca}^{2+}$ channels (Figs. 3 and 4 ), the mean $\mathrm{Ca}^{2+}$ current reduction of $28 \pm 4 \%$ that we observed at saturating concentrations (16 nM) appears of functional relevance for two reasons. First, because QDs significantly reduces the quantity of released catecholamines (adrenaline and 
A

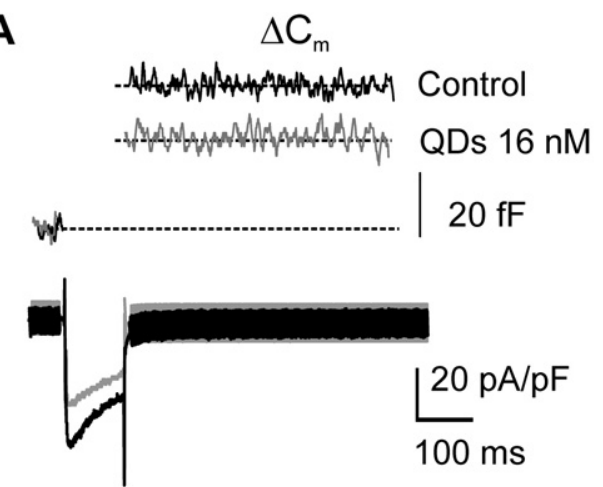

C

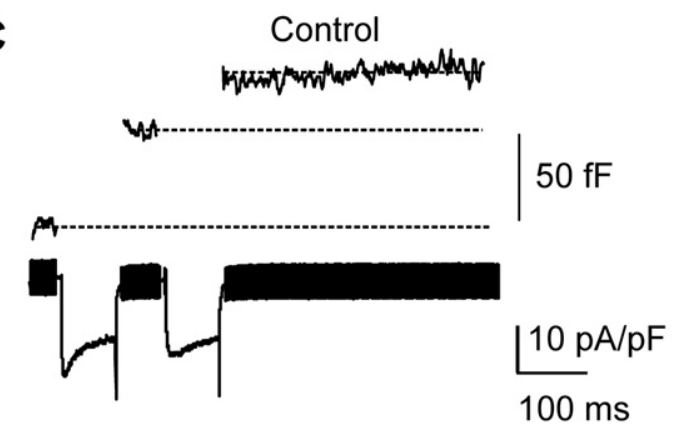

B

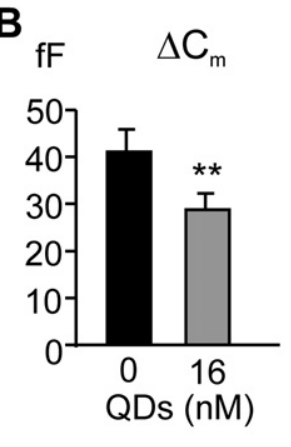

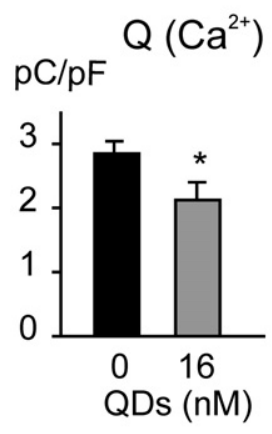

D

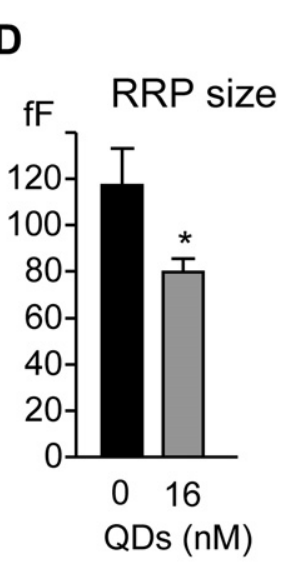

E

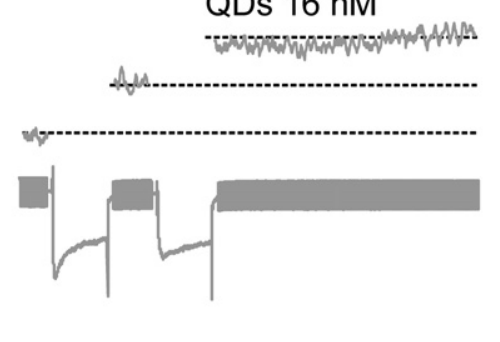

QDs $16 \mathrm{nM}$
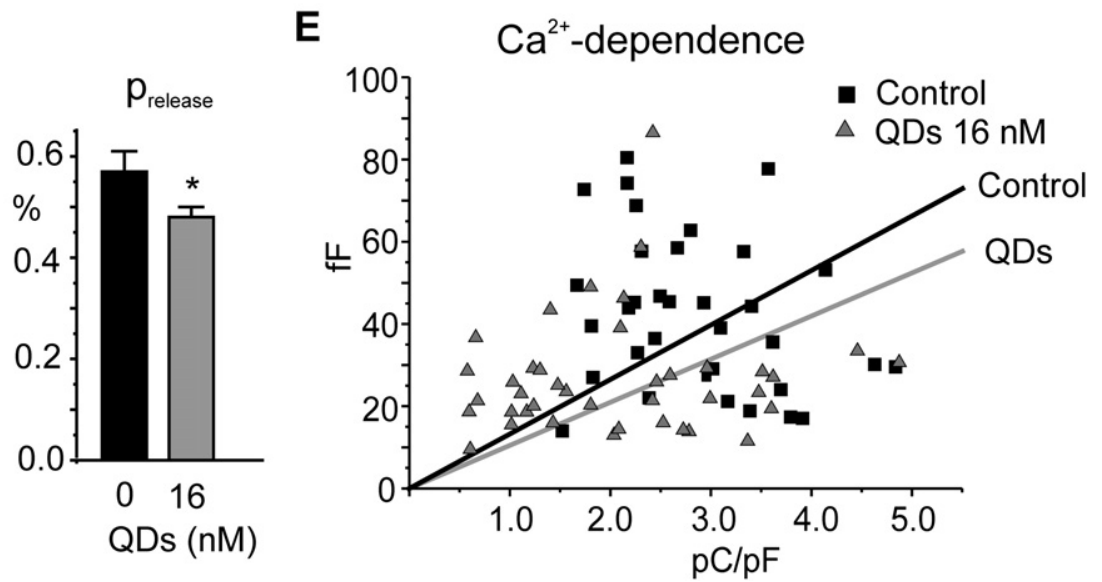

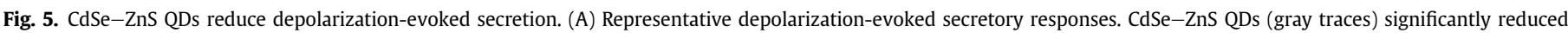

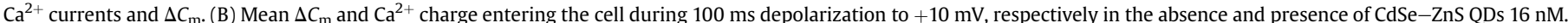

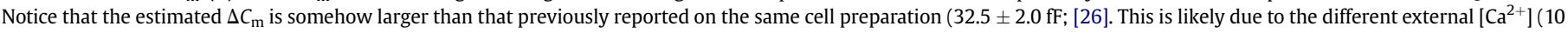

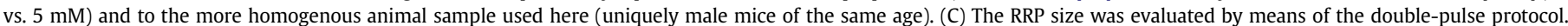

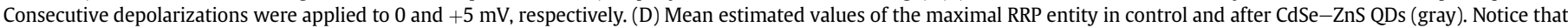

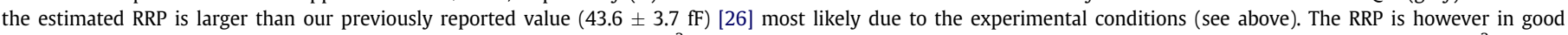

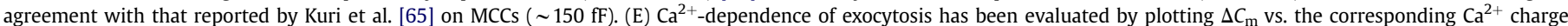
density. The slope of linear fit was $(13.2 \pm 1.4) \mathrm{fF} /(\mathrm{pC} / \mathrm{pF})$ for controls and $(10.5 \pm 1.2) \mathrm{fF} /(\mathrm{pC} / \mathrm{pF})$ for $\mathrm{QDs}(p<0.05)$.

noradrenaline). Second, because QDs attenuates the high-threshold $\mathrm{Ca}^{2+}$ currents (L, N, P/Q and R-type) that regulate the action potential shape and the spontaneous firing frequency of MCCs at rest [43] through the activation of $\mathrm{Ca}^{2+}$-dependent $\mathrm{BK}$ and SK potassium channels. BK and SK channels are highly expressed in MCCs and regulate the speed of AP repolarization, burst firing duration and interspikes interval [49]. Thus, a reduction of available $\mathrm{Ca}^{2+}$ channels by QDs may cause significant changes to action potential shape and cell firing that are not easily predictable. Apart from this issue, we can draw interesting conclusions concerning the voltage-independent action of QDs on $\mathrm{Ca}^{2+}$ currents reduction that we observed in a broad range of voltages $(+50$ to $-80 \mathrm{mV})$. A voltage-independent reduction of $\mathrm{Ca}^{2+}$ currents would exclude a possible blocking effect of $\mathrm{Ca}^{2+}$ channels by free intracellular $\mathrm{Cd}^{2+}$ (or $\mathrm{Zn}^{2+}$ ) ions released from the core or the outer shell of QDs. Direct block of $\mathrm{Ca}^{2+}$ channels by $\mathrm{Cd}^{2+}\left(\right.$ or $\left.\mathrm{Zn}^{2+}\right)$ would be strongly voltage-dependent, i.e., maximal around $0 \mathrm{mV}$ and largely removed at very negative voltages $(-80 \mathrm{mV})$ due to the massive inward passage of $\mathrm{Ca}^{2+}$ ions and/or lowering of the energy barrier that would facilitate the exit rate of $\mathrm{Cd}^{2+}$ or $\mathrm{Zn}^{2+}$ ions from their binding sites inside the channel pore [50] (see Results). It is likely therefore that the QDs-induced cytotoxicity observed here derives from the generation of free radicals or other toxic factors associated to the partial release of the core/shell metal constituent that act by 
A
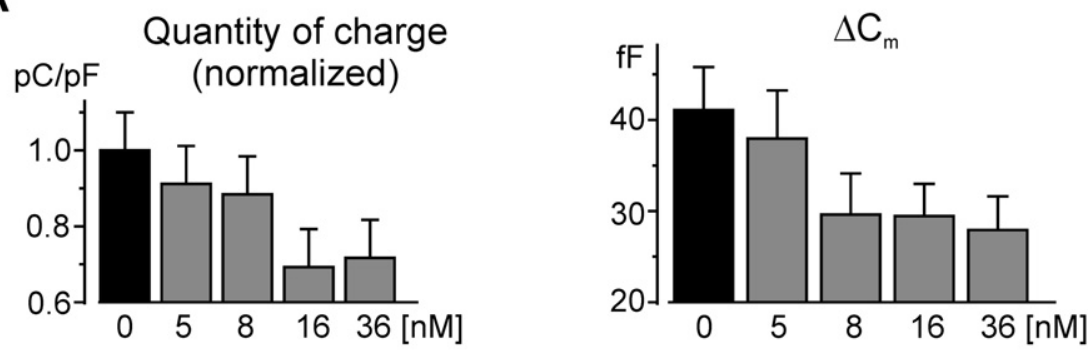

B

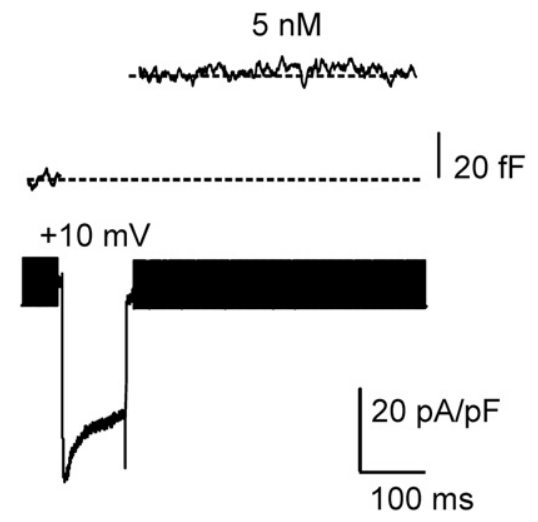

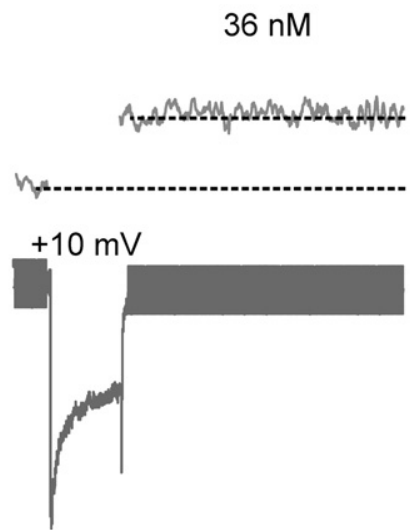

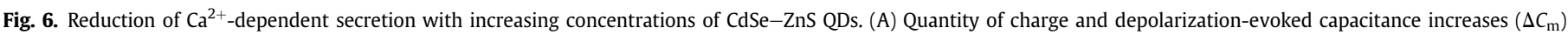

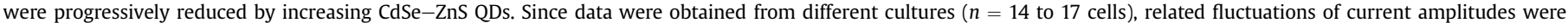

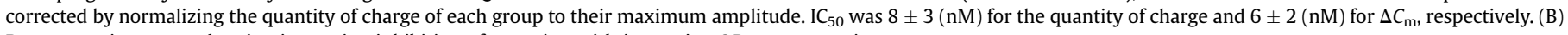
Representative traces showing increasing inhibition of secretion with increasing QDs concentrations.

decreasing the number of functioning $\mathrm{Ca}^{2+}$ channels with little or no effects on their gating properties and membrane integrity (Figs. 2 and 4). Notice that this nanoparticle toxicity is markedly different from that induced by multi-walled carbon nanotubes (MWCNT), which lower membrane resistance without affecting $\mathrm{Ca}^{2+}$ currents in the same cell preparation [51]. In addition, it is also worth noticing that QDs action on ion channels is rather heterogeneous, depending on nanoparticle functionalization and cell model. CdSe-ZnS QDs (nanomolar range) had no effect on hERG and inward rectified $\mathrm{K}^{+}$channels in rat basophilic leukemia (RBL) and $\mathrm{CHO}$ Chinese hamster ovary (CHO) cell lines [52]. Acute exposure of unmodified CdSe QDs have been shown to potentiate $\mathrm{Ca}^{2+}$ influx and enhance $\mathrm{Na}^{+}$channels inactivation in hippocampal neurons $[23,25]$.

Our data are in-line with a number of reports in which the core metal constituents of QDs are shown to exert toxic effects on cell functioning, mostly through the oxidation of QDs, decomposition of $\mathrm{CdSe} / \mathrm{CdTe}$ nanocrystals, and release of free $\mathrm{Cd}^{2+}$ ions and/or CdSe complex from the core $[15,53,54]$. It is shown in fact that QDsinduced cellular damage can be limited by protecting the core from degradation using surface coating (a ZnS layer or a silica shell). This limits $\mathrm{Cd}^{2+}$ leaks from the core and reduces free radical generation. In support of this, $\mathrm{ZnS}$ core/shell particles are shown to reduce apoptosis and JNK activation [55], although, it should be noticed that the ZnS shell does not completely eliminate cytotoxicity and that degradation of the shell or capping material occurs over prolonged QDs exposures [56,57].

In agreement with most in vitro studies, we also found a decreased chromaffin cell viability after $24 \mathrm{~h}$ of CdSe-ZnS QDs exposure ( $\geq 16 \mathrm{nM})[23,27,58]$, confirming that cell apoptosis occurs to some degree unless a specific nanoparticle functionalization is performed, as in the case of $\mathrm{SiO}_{2}$-doped $\mathrm{QD}$ internalized into cortical neurons that drastically increases cell viability [59]. In this respect, it is worth mentioning that while unmodified $\mathrm{CdSe} / \mathrm{CdTe}$ QDs cause morphological changes such as loss of plasma membrane integrity, chromatin condensation and damage to mitochondria and nuclei [54], CdSe-ZnS QDs internalization in MCCs preserves membrane integrity, as monitored by the unaltered cell membrane resistance (Fig. 2) [42,60]. This action is again distinct from that of MWCNTs, which are shown to increase membrane leakage (lower membrane resistance) and penetrate the cell nuclei during prolonged exposures [51].

Concerning QDs internalization, we found that $24 \mathrm{~h}$ exposure to CdSe-ZnS QDs (16 nM) were sufficient for their complete uptake during resting cell conditions. Although other pathways cannot be ruled out, it is likely that in MCCs, QDs internalization occurs mainly through clathrin-mediated endocytosis following the basal secretory activity of chromaffin cells at rest $[9,32,34,61]$. This explains the bright fluorescent dots in correspondence of the secretory granules of 200-400 nm diameters and the absence of diffused fluorescence in the nucleus (Fig. 1), as observed in other cell preparations [38-40]. However, since the mechanism of cellular uptake strongly depends on nanoparticles size and shape and is still largely unknown [3,62], it is also possible that a fraction of CdSe-ZnS QDs enters the chromaffin cells by diffusion across the plasma membrane. These nanocrystals may interfere with the cell membrane, the cytoskeleton and the microfilaments controlling the movements of secretory granules near the cell membrane, and alter the rate of membrane vesicle fusion and catecholamine release (Figs. 5 and 7).

An important issue of our findings is the reduced amount of catecholamine release following exposure to $\mathrm{CdSe}-\mathrm{ZnS}$ QDs (Fig. 7). Part of the decrease is certainly due to the reduced amount of $\mathrm{Ca}^{2+}$ influx through voltage-gated $\mathrm{Ca}^{2+}$ channels during 


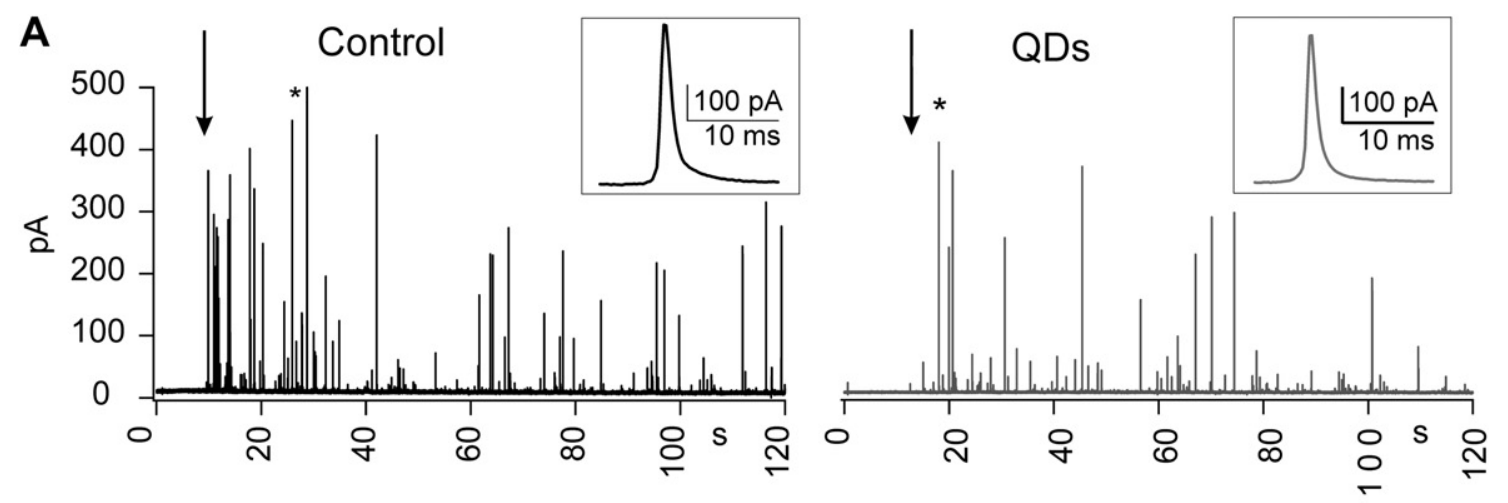

B
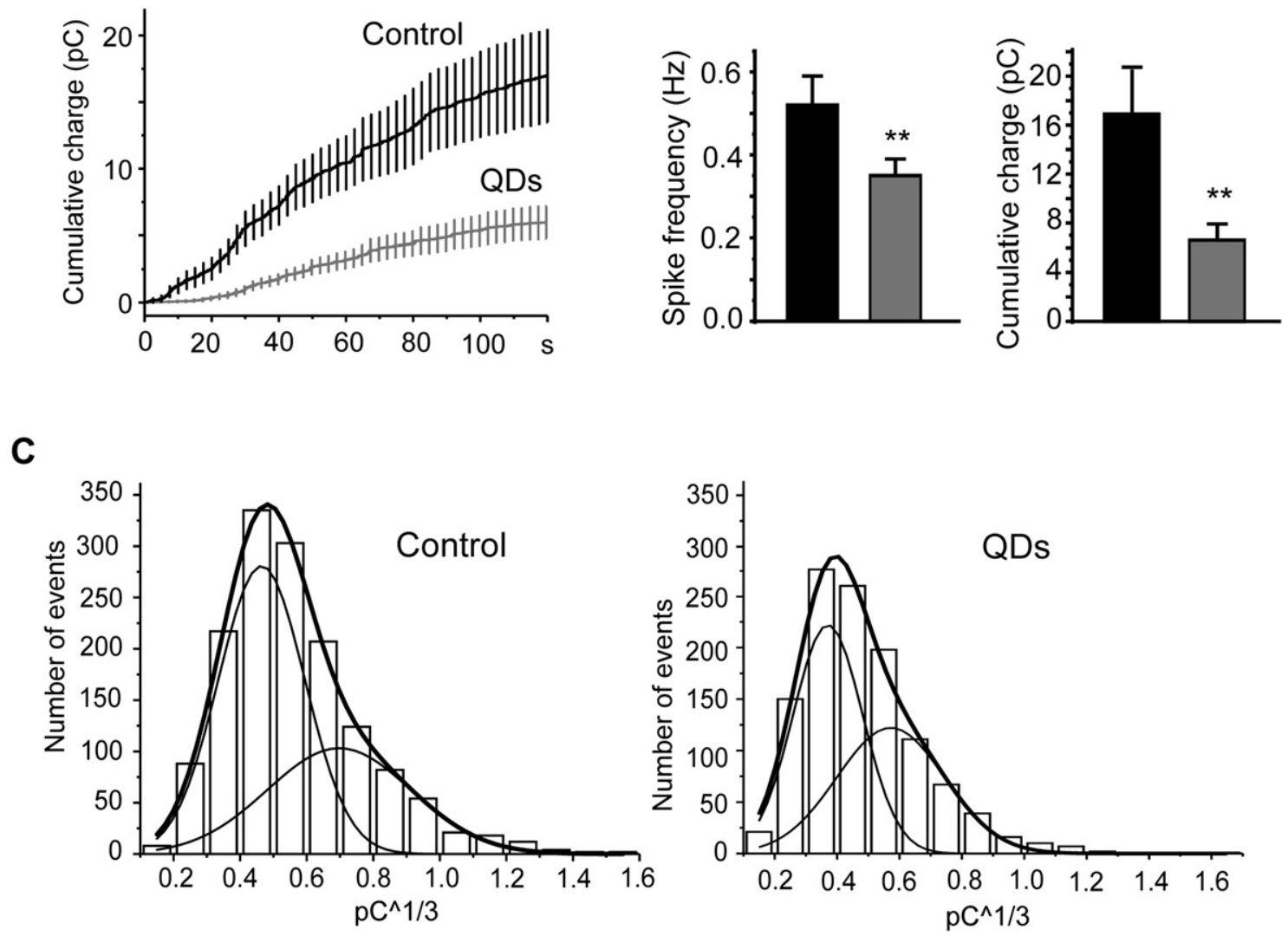

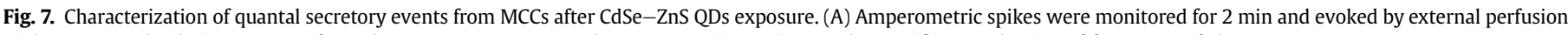

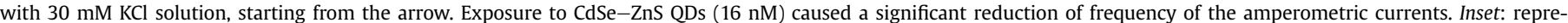

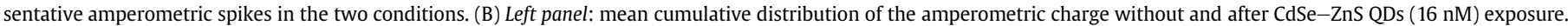

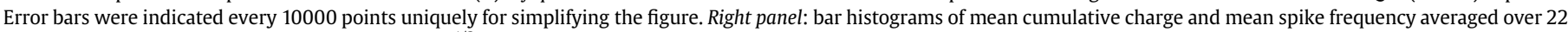

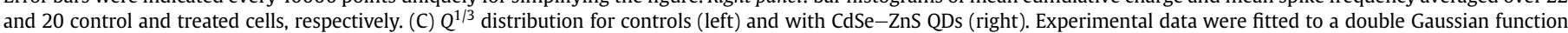
(see text for details).

depolarization-induced exocytosis. However, QDs decrease also the size of the RRP and the probability of vesicle release as shown by the increased $\Delta C_{2} / \Delta C_{1}$ capacitance ratio during double-pulse depolarizations and the lower rate of amperometric bursts during

Table 1

Mean values of amperometric spike parameters for control cells and after QDs incubation. $I_{\max }$ : maximal current amplitude, $Q$ : charge of the spike, $t_{1 / 2}$ : half-height width, $\mathrm{m}$ : slope of the rising phase, $t_{\mathrm{p}}$ : time to peak.

\begin{tabular}{lllllll}
\hline & $I_{\max }(\mathrm{pA})$ & $\mathrm{Q}(\mathrm{pC})$ & $\mathrm{Q}^{1 / 3}\left(\mathrm{pC}^{1 / 3}\right)$ & $t_{1 / 2}(\mathrm{~ms})$ & $m(\mathrm{nA} / \mathrm{s})$ & $t_{\mathrm{p}}(\mathrm{ms})$ \\
\hline Control & $39 \pm 5$ & $0.23 \pm 0.02$ & $0.54 \pm 0.02$ & $6.2 \pm 0.3$ & $18 \pm 3$ & $4.2 \pm 0.2$ \\
QDs & $32 \pm 6$ & $0.21 \pm 0.04$ & $0.50 \pm 0.02$ & $6.0 \pm 0.5$ & $14 \pm 2$ & $4.1 \pm 0.2$ \\
\hline
\end{tabular}

$\mathrm{KCl}$-induced exocytosis. The depression of exocytosis is more dramatic when observing the quantity of released catecholamines during 2 min long $\mathrm{KCl}$ depolarization (61\%; Fig. 7B) where besides the RRP also the "slowly releasable" pool (SRP) of vesicles contributes to the sustained secretion. This occurs with little changes of both the catecholamine content of single granules and their kinetics of release measured from amperometric recordings, suggesting that QDs internalization interferes with the secretory apparatus without much affecting the mechanism of single vesicle replenishment or catecholamine detachment from the intragranular matrix. Most likely the decreased size of the RRP and probability of vesicle release derive from either an altered coupling 
between $\mathrm{Ca}^{2+}$ channels and the secretory apparatus or from an altered functionality of microfilaments and membrane anchoring proteins, which regulate vesicle docking to the plasma membrane and vesicle movements from the SRP to the RRP pool. Concerning this issue, there are reports showing that QDs binds to F-actin and shrinks actin cytoskeleton rings of renal epithelial cells [38], moreover $\mathrm{Cd}^{2+}$ ions are shown to depolymerize F-actin and affect the cadherin-catenin complex in the same cell type [63]. As F-actin is postulated to play a role in controlling secretory granule access to the plasma membrane [64] it is thus possible that $\mathrm{Cd}^{2+}$ ions released from QDs reduce neurosecretion by disassembling the $\mathrm{F}$ actin cytoskeleton rings near the plasma membrane and the formation of the SNARE complex which regulates the "kiss-andrun" and "full-collapse fusion" processes preceding catecholamine release. A consequence of this would be a marked reduction of the RRP and frequency of secretory events.

Despite a number of studies on QDs cytotoxicity, little is known about the effects of nanoparticles on neurosecretion and synaptic transmission. The only report to our knowledge deals with the acute action of CdSe and CdSe-ZnS QDs on field-evoked pairedpulse ratio and LTP synaptic plasticity in in-vivo hippocampal dentate gyrus area of anesthetized rats [25]. Both parameters are reduced due to an increased level of presynaptic $\mathrm{Ca}^{2+}$, deriving from an increased extracellular $\mathrm{Ca}^{2+}$ influx and $\mathrm{Ca}^{2+}$ released from intracellular stores. Obviously, these acute effects of QDs following 2-3 min application are at variance from those reported here on MCCs exposed for $24 \mathrm{~h}$ to QDs. Acute versus chronic exposure to QDs may very likely cause different time-dependent cytotoxic effects on neurotransmission.

\section{Conclusions}

Given the rapidly growing use of QDs for medical diagnosis and therapy, in-vitro and in-vivo studies using QDs demand for a careful evaluation of their potential cytotoxic effects on cell viability and functionality, as well as on health hazard. Future experiments should be addressed to investigate more deeply the QDs-induced alterations of the molecular events regulating $\mathrm{Ca}^{2+}$-dependent neurotransmitter release in chromaffin cells with the ultimate idea that these findings could help better understanding the cytotoxic effects of semiconductor nanocrystal QDs in other neuroendocrine cells and central neuron synapses.

\section{Acknowledgments}

This work was supported by the Foundation Compagnia di SanPaolo "Neuroscience program" to VC, Regione Piemonte "Nanosafe program" to EC and by CRT Foundation "Alfieri project" to EC and VC.

\section{References}

[1] Hardman R. A toxicologic review of quantum dots: toxicity depends on physicochemical and environmental factors. Environ Health Perspect 2006; 114(2):165-72.

[2] Hoshino A, Fujioka K, Oku T, Suga M, Sasaki T, Ohta M, et al. Physicochemical properties and cellular toxicity of nanocrystal quantum dots depend on their surface modifications. Nano Lett 2004;4:2163-88.

[3] Zhang LW, Monteiro-Riviere NA. Mechanism of quantum dot nanoparticle cellular uptake. Toxicol Sci 2009;110(1):138-55

[4] Azzazy HME, Mansour MMH. In vitro diagnostic prospects of nanoparticles. Clin Chim Acta 2009;403:1-8.

[5] Peng CW, Li Y. Application of quantum dots-based biotechnology in cancer diagnosis: current status and future perspectives. J Nanomater 2010;2010 $1-12$.

[6] Dubertret B, Skourides P, Norris DJ, Noireaux V, Brivanlou AH, Libchaber A. In vivo imaging of quantum dots encapsulated in phospholipid micelles. Science 2002;298:1759-62.
[7] Chang Y-P, Pinaud F, Antelman J, Weiss S. Tracking bio-molecules in live cells using quantum dots. J Biophoton 2008;1(4):287-98.

[8] Kobayashi H, Hama Y, Koyama Y, Barrett T, Regino CAS, Urano Y, et al. Simultaneous multicolor imaging of five different lymphatic basins using quantum dots. Nano Lett 2007;7:1711-6.

[9] Zhang Q, Li Y, Tsien RW. The dynamic control of kiss-and-run and vesicular reuse probed with single nanoparticles. Science 2009;323(5920):1448-53.

[10] Won S, Kim HD, Kim JY, Lee BC, Chang S, Park CS. Movements of individual BK Ca channels in live cell membrane monitored by site-specific labeling using quantum dots. Biophys J 2010;399:2853-62.

[11] Choi AO, Brown SE, Szyf M, Maysinger D. Quantum dot induced epigenetic and genotoxic changes in human breast cancer cells. J Mol Med 2008;86:291-302.

[12] Choi HS, Frangioni JV. Nanoparticles for biomedical imaging: fundamentals of clinical translation. Mol Imaging 2010;9(6):291-310.

[13] Pelley JL, Daar AS, Saner MA. State of academic knowledge on toxicity and biological fate of quantum dots. Toxicol Sci 2009;112(2):276-96.

[14] Rzigalinski BA, Strobl JS. Cadmium-containing nanoparticles: perspectives on pharmacology and toxicology of quantum dots. Toxicol Appl Pharmacol 2009; 238:280-8.

[15] Das GK, Chan PP, Teo A, Loo JS, Anderson JM, Tan TT. In vitro cytotoxicity evaluation of biomedical nanoparticles and their extracts. J Biomed Mater Res A 2010;93(1):337-46.

[16] Alivisatos AP, Gu W, Larabell C. Quantum dots as cellular probes. Annu Rev Biomed Eng 2005; 7:55-76.

[17] Clarke SJ, Hollmann CA, Aldaye FA, Nadeau JL. Effect of ligand density on the spectral, physical, and biological characteristics of $\mathrm{CdSe} / \mathrm{ZnS}$ quantum dots. Bioconjug Chem 2008;19:562-8.

[18] Michalet X, Pinaud FF, Bentolila LA, Tsay JM, Doose S, Li JJ, et al. Quantum dots for live cells, in vivo imaging, and diagnostics. Science 2005;307(5709): 538-44.

[19] Hsieh SC, Wang FF, Hung SC, Chen YJ, 1Wang YJ. The internalized CdSe/ZnS quantum dots impair the chondrogenesis of bone marrow mesenchymal stem cells. J Biomed Mater Res B: Appl Biomater 2006;79(1):95-101.

[20] Kuo T-R, Lee C-F, Lin S-J, Dong CY, Chen C-C, Tan H- Y. Studies of intracorneal distribution and cytotoxicity of quantum dots: risk assessment of eye exposure. Chem Res Toxicol 2011;24:253-61.

[21] Clift MJ, Boyles MS, Brown DM, Stone V. An investigation into the potential for different surface-coated quantum dots to cause oxidative stress and affect macrophage cell signaling in vitro. Nanotoxicology 2010;4(2):139-49.

[22] Tang M, Wang M, Xing T, Zeng J, Wang H, Ruan DY. Mechanisms of unmodified CdSe quantum dot-induced elevation of cytoplasmic calcium levels in primary cultures of rat hippocampal neurons. Biomaterials 2008;29(33): 4383-91.

[23] Tang M, Xing T, Zeng J, Wang H, Li C, Yin S, et al. Unmodified CdSe quantum dots induce elevation of cytoplasmic calcium levels and impairment of functional properties of sodium channels in rat primary cultured hippocampal neurons. Environ Health Perspect 2008;116(7):915-22.

[24] Vu TQ, Maddipati R, Blute TA, Nehilla BJ, Nusblat L, Desai TA. Peptide-conjugated quantum dots activate neuronal receptors and initiate downstream signaling of neurite growth. Nano Lett 2005;5(4):603-7.

[25] Tang M, Li Z, Chen L, Xing T, Hu Y, Yang B, et al. The effect of quantum dots on synaptic transmission and plasticity in the hippocampal dentate gyrus area of anesthetized rats. Biomaterials 2009;30(28):4948-55.

[26] Marcantoni A, Carabelli V, Vandael DH, Comunanza V, Carbone E. PDE type-4 inhibition increases L-type $\mathrm{Ca}^{2+}$ currents, action potential firing, and quantal size of exocytosis in mouse chromaffin cells. Pflügers Arch Europ J Physiol 2009;457(5):1093-110.

[27] Gillis KD, Mossner R, Neher E. Protein kinase C enhances exocytosis from chromaffin cells by increasing the size of the readily releasable pool of secretory granules. Neuron 1996;16(6):1209-20.

[28] Carabelli V, Marcantoni A, Comunanza V, de Luca A, Díaz J, Borges R, et al. Chronic hypoxia up-regulates alpha1H T-type channels and low-threshold catecholamine secretion in rat chromaffin cells. J Physiol (Lond) 2007;584: 149-65.

[29] Santos AR, Miguel1 AS, Tomaz L, Malhó R, Maycock C, Vaz Patto MC, et al. The impact of CdSe/ZnS quantum dots in cells of Medicago sativa in suspension culture. J Nanobiotec 2010;8(24):1-14.

[30] van Dooren BT, Beekuis WH, Pels E. Biocompatibility of trypan blue with human corneal cells. Arch Opthalmol 2004;122(5):736-42.

[31] Bertinaria M, Rolando B, Giorgis M, Montanaro G, Guglielmo S, Buonsanti MF, et al. Synthesis, physicochemical characterization, and biological activities of new carnosine derivatives stable in human serum as potential neuroprotective agents. J Med Chem 2011;54:611-21.

[32] Anas A, Okuda T, Kawashima N, Nakayama K, Itoh T, Ishikawa M, et al. Clathrin-mediated endocytosis of quantum dot peptide conjugates in living cells. ACS Nano 2009;3(8):2419-29.

[33] Chithrani BD, Chan WCW. Elucidating the mechanism of cellular uptake and removal of protein-coated gold nanoparticles of different sizes and shapes. Nano Lett 2007; 7:1542-50.

[34] Jiang X, Röcker C, Hafner M, Brandholt S, Dörlich RM, Nienhaus GU. Endo- and exocytosis of zwitterionic quantum dot nanoparticles by live Hela cells. ACS Nano 2010;4(11):6787-97.

[35] Lidke DS, Nagy P, Heintzmann R, Arndt-Jovin DJ, Post JN, Grecco HE, et al. Quantum dot ligands provide new insights into erbB/HER receptor-mediated signal transduction. Nat Biotechnol 2004;22:198-203. 
[36] Maysinger D, Lovric J, Eisenberg A, Savic R. Fate of micelles and quantum dots in cells. Eur J Pharm Biopharm 2007;65:270-81.

[37] XiaoY Forry SP, Gao X, Holbrook RD, Telford WG, Tona A. Dynamics and mechanisms of quantum dot nanoparticle cellular uptake. J Nanobiotec 2010;8:13.

[38] Tarantola M, Schneider D, Sunnick E, Adam H, Pierrat S, Rosman C, et al. Cytotoxicity of metal and semiconductor nanoparticles indicated by cellular micromotility. ACS Nano 2009;3(1):213-22.

[39] Stern ST, Zolnik BS, McLeland CB, Clogston J, Zheng J, McNeil SE. Induction of autophagy in porcine kidney cells by quantum dots: a common cellular response to nanomaterials? Toxicol Sci 2008;106(1):140-52.

[40] Lewinski N, Colvin V, Drezek R. Cytotoxicity of nanoparticles. Small 2008;4: 26-49.

[41] Prasad BR, Nikolskaya N, Connolly D, Smith TJ, Byrne SJ, Gérard VA, et al. Long -term exposure of CdTe quantum dots on PC12 cellular activity and the determination of optimum non-toxic concentrations for biological use. J Nanobiotec 2010;8(7):2-16.

[42] Koeneman BA, Zhang Y, Hristovski K, Westerhoff P, Chen Y, Crittenden JC, et al. Experimental approach for an in vitro toxicity assay with nonaggregated quantum dots. Toxicol in Vitro 2009;23:955-62.

[43] Marcantoni A, Vandael DHF, Mahapatra S, Carabelli V, Sinneger-Brauns MJ, Striessnig J, et al. Loss of Cav1.3 channels reveals the critical role of L-type and BK channel coupling in pacemaking mouse adrenal chromaffin cells. J Neurosci 2010;30:491-504.

[44] Carabelli V, Giancippoli A, Baldelli P, Carbone E, Artalejo AR. Distinct potentiation of L-type currents and secretion by cAMP in rat chromaffin cells. Biophys J 2003;85:1326-37.

[45] Carabelli V, Carra I, Carbone E. Localized secretion of ATP and opioids revealed through single $\mathrm{Ca} 2+$ channel modulation in bovine chromaffin cells. Neuron 1998;20(6):1255-68.

[46] Mahapatra S, Marcantoni A, Vandael DHF, Striessnig J, Carbone E. Are Cav1.3 pacemaker channels in chromaffin cells? Possible bias from resting cell conditions and DHP blocker usage. Channels (Austin) 2011;5(3):219-24.

[47] Grabner CP, Price SD, Lysakowski A, Fox AP. Mouse chromaffin cells have two populations of dense core vesicles. J Neurophysiol 2005;94(3):2093-104.

[48] García AG, García-De-Diego AM, Gandía L, Borges R, García-Sancho J. Calcium signaling and exocytosis in adrenal chromaffin cells. Physiol Rev 2006;86(4): 1093-131.

[49] Vandael DH, Marcantoni A, Mahapatra S, Caro A, Ruth P, Zuccotti A, et al Cav1.3 and BK channels for timing and regulating cell firing. Molec Neurobiol 2010;41:185-98.

[50] Swandulla D, Armstrong CM. Calcium channel block by cadmium in chicken sensory neurons. Proc Nat Acad Sci U S A 1989;86:1736-40.

[51] Gavello D, Vandael DH, Cesa R, Premoselli F, Marcantoni A, Cesano F, et al. Altered excitability of cultured chromaffin cells following exposure to multi-walled carbon nanotubes. Nanotoxicology; 2011. doi:10.3109/17435390.2011.553294.
[52] Kirchner C, Liedl T, Kudera S, Pellegrino T, Munoz Javier A, Gaub HE, et al Cytotoxicity of colloidal CdSe and CdSe/ZnS nanoparticles. Nano Lett 2005; 5(2):331-8.

[53] Derfus AM, Chan WC, Bhatia S. Probing the cytotoxicity of semiconductor quantum dots. Nano Lett 2004;4:11-8.

[54] Lovric J, Cho SJ, Winnik FM, Maysinger D. Unmodified cadmium telluride quantum dots induce reactive oxygen species formation leading to multiple organelle damage and cell death. Chem Biol 2005;12:1227-34.

[55] Chan WH, Shiao NH, Lu PZ. CdSe quantum dots induce apoptosis in human neuroblastoma cells via mitochondrial-dependent pathways and inhibition of survival signals. Toxicol Lett 2006;167:191-200.

[56] Zhang T, Stilwell JL, Gerion D, Ding L, Elboudwarej O, Cooke PA, et al. Cellular effect of high doses of silica-coated quantum dot profiled with high throughput gene expression analysis and high content cellomics measurements. Nano Lett 2006;6(4):800-8.

[57] Zhang Y, He J, Wang PN, Chen JY, Lu ZJ, Da-Ru L, et al. Timedependent photoluminescence blue shift of the quantum dots in living cells: effect of oxidation by singlet oxygen. J Am Chem Soc 2006b; 128:13396-401.

[58] Ryman-Rasmussen JP, Riviere JE, Monteiro-Riviere NA. Surface coatings determine cytotoxicity and irritation potential of quantum dot nanoparticles in epidermal keratinocytes. J Invest Dermatol 2007;127:143-53.

[59] Bardi G, Malvindi MA, Gherardini L Costa M, Pompa PP, Cingolani R, et al. The biocompatibility of amino functionalized $\mathrm{CdSe} / \mathrm{ZnS}$ quantum-dot-doped $\mathrm{SiO}_{2}$ nanoparticles with primary neural cells and their gene carrying performance. Biomaterials 2010;31(25):6555-66.

[60] Yacobi NR, Phuleria HC, Demaio L, Liang CH, Peng CA, Sioutas C, et al. Nanoparticle effects on rat alveolar epithelial cell monolayer barrier properties. Toxicol in Vitro 2007;21:1373-81.

[61] Aaron S, Greene AC, Kotula PG, Bachand GD, Timlin JA Advanced optica imaging reveals the dependence of particle geometry on interactions between CdSe quantum dots and immune cells. Small 2011;7(3):334-41.

62] Delehanty JB, Bradburne CE, Boeneman K, Susumu K, Farrell D, Mei BC, et al. Delivering quantum dot-peptide bioconjugates to the cellular cytosol: escaping from the endolysosomal system. Integr Biol 2010;2:265-77.

63] Zimmerhackl LB, Momm F, Wiegele G, Brandis M. Cadmium is more toxic to LLC-PK1 cells than to MDCK cells acting on the cadherin-catenin complex. Am J Physiol Renal Physiol 1998;275:F143-53.

[64] Trifaró JM, Lejen T, Rosé SD, Pene TD, Barkar ND, Seward EP. Pathways that control cortical F-actin dynamics during secretion. Neurochem Res 2002; 27(11):1371-85.

[65] Kuri BA, Khan SA, Chan SA, Prabhakar NR, Smith CB. Increased secretory capacity of mouse adrenal chromaffin cells by chronic intermittent hypoxia: involvement of protein kinase. J Physiol (Lond) 2007;584:313-9. 